DOI:10.32703/2617-9040-2021-37-9

UDC 656.073

Alexander Krasheninin", Olha Shapatina ${ }^{2 *}$, Vitaliy Ponomarenko ${ }^{3}$

${ }^{1}$ Professor, Department of Operation and Repair of Rolling Stock, Ukrainian State University of Railway Transport, Feuerbach Square, 7, Kharkiv, 61050, Ukraine. ORCID: https://orcid.org/0000-0001-7462-3372

2 Senior Lecturer, Department of cargo and commercial work management, Ukrainian State University of Railway Transport, Feuerbach Square, 7, Kharkiv, 61050, Ukraine. ORCID: https://orcid.org/0000-0002-91856212

${ }^{3}$ Senior Lecturer, Department of foreign languages, Ukrainian State University of Railway Transport, Feuerbach Square, 7, Kharkiv, 61050, Ukraine. ORCID: https://orcid.org/0000-0002-1820-4277

*Corresponding author: shapatina@ukr.net

\title{
ESTIMATION OF VEHICLE OPERATING TIME TAKING INTO ACCOUNT THE INFLUENCE OF A NUMBER OF FACTORS
}

Modern vehicles operated on the railways of Ukraine have almost exhausted or exceeded their resource. The overuse of financial and material resources for their maintenance continues. The standard service life of vehicles was calculated on stable economic conditions of use of vehicles and their timely updating in process of aging.

The service life of modern vehicles is determined by the influence of many factors, the disregard of which can lead to significant costs, even in compliance with the standard service life.

For railway transport, these factors need modern clarification, as in operation their service life often exceeds the standard or, as for intermodal transport, the service life does not have a strict justification.

Accordingly, the article analyzes the issues of assessing the impact on the service life of vehicles of the components of the cost of its maintenance and average daily mileage.

It is shown that, firstly, the definition of the service life of vehicles must be linked to the cost of vehicle development, its creation, testing and production, the cost of operation and storage, as well as additional costs, and secondly, with the optimal average daily mileage, at which all the costs are minimal.

Keywords: vehicle, optimal average daily mileage, service life, minimum reduced costs

Introduction. In recent years, the railway has remained the main industry for the massive transport of passengers and goods. In modern conditions, it is increasingly difficult for the railways to ensure the transportation process, mainly due to the deterioration of the infrastructure and the slow renewal of the locomotive and wagon fleet.

Against this background, it becomes more and more difficult for a vehicle to compete with road transport not only in the carriage of passengers, but also in freight transport, especially for short and medium distances.

In these conditions, attention should be paid to modern vehicles, in particular, intermodal transport, the use of which in some foreign countries has reached $40 \%$ in the volume of cargo transportation by all means of transport. For our country, it represents a significant additional reserve in the use of the railway infrastructure. Already now it is necessary to formulate a policy of retaining new vehicles, taking into account the accumulated experience of railway transport. 
Analysis of recent research and problem statement. The development and optimization of the work of new transport systems are devoted to the works of Aleshinskiy E.S., Butko T.V., Vernigora R.V., Demin Yu.V., Kirpa G.M., Kozachenko D.M., Kotenko A.M. , Lomotko D. V., Postan M. Ya., Reser S. M., Shibaeva A. G., Yanovsky P. A. and others.

Considerable attention is paid to theoretical and practical issues of using new types of transport both in our country and abroad.

So, at the Department of Operation and Repair of Rolling Stock and Department of Cargo and Commercial work of UkrDUZT, a number of studies were carried out related to determining the efficiency of transportation by intermodal transport [1-4].

Abroad, these works have received practical meaning for a long time. So, in European countries, intermodal transportation is widely used due to their greater environmental friendliness, low cost and mobility [5-7]. Also, intermodal transport contributes to increasing the competitiveness of rail transport, while ensuring the delivery of goods "from door to door" [8-10].

The use of the technology of piggyback, container and bimodal routes allows to reduce the cost of transportation, helps to reduce the delivery time of goods and improve the quality of freight traffic [11-13].

UkrDUZT also carried out fundamental research to substantiate the timing of a more standardized use of traction rolling stock $[14,15]$, the accounting of which will allow to determine the optimal costs and quality indicators of the use of other vehicles.

The purpose and tasks of the study.

The purpose of this work is to assess and simulate the influence of a number of factors on the overall service life of a vehicle to ensure optimal reduced costs for their maintenance.

In accordance with this, the following tasks have been set:

to determine the factors affecting the service life of the vehicle;

to develop an algorithm for assessing the costs of these factors to ensure the optimal service life of the vehicle and the required average daily mileage of the vehicle;

to evaluate the effectiveness of interaction of various types of transport.

\section{Materials and methods of research.}

The efficiency of a vehicle with a service life must be assessed taking into account a set of the following factors: the function of the need for a vehicle and the costs associated with the entire structure of the life cycle.

Let us formalize the problem as follows. Let the demand function of some argument be given: integral $F(x)$ or differential $f(x)$. There has been given the function of the cost of producing one vehicle from this argument $Z_{0}(x)$, the cost of developing, testing and delivering the vehicle production $Z_{p}(x)$, the cost of operating or storing the vehicle per unit of time $Z_{p}(x)$.

It is necessary to determine the optimal number of vehicle types and such values of their arguments, at which the total costs will be minimal.

It is important to select the types $N$, the arguments $x_{1}, x_{2}, \ldots, x_{N}$ of which, and each vehicle of the type $\kappa$ is applied in the range of the argument from $x_{\kappa-1}$ to $x_{\kappa}$. Then the total costs can be determined by the formula.

$$
C_{N}=\sum_{k=0}^{N}\left(F\left(x_{k+1}\right)-F\left(x_{k}\right)\right) \cdot Z_{0}\left(x_{k+1}\right)+\sum_{k=0}^{N} Z_{p}\left(x_{k+1}\right)+\int_{0}^{T} \sum_{k=0}^{N} Z_{c}\left(x_{k+1}\right)\left[F\left(x_{k+1}\right)-F\left(x_{k}\right)\right] d t \rightarrow \min
$$


It is necessary to determine such a set $x_{\kappa}$, including $N$, at which the value $C_{N}$ will be minimal. The given problem is one-dimensional, since it has one parameter.

In practice, the fulfillment of the condition when the vehicle can be used with the argument values less than the corresponding type and more than the previous ones is not required. That is, a vehicle with a standard service life can be used in excess of the standard period, which is associated with additional costs.

The value of the argument $x_{\kappa}$ characterizes the given type of vehicle, and the value of the argument to which this type of vehicle is applied is denoted $z_{k}$. We denote the function of need $F(x)$, the cost of production of one vehicle $Z_{0}\left(x_{k}\right)$, the cost of development, testing and delivery of a vehicle for production $Z_{p}\left(x_{k}\right)$, the cost of operating or storing a vehicle per unit of time $Z_{c}\left(x_{k}\right)$, additional costs per vehicle per unit of time $Z_{\partial}\left(\frac{z}{x_{k}}\right)$. Then we have the formula (1) as follows

$$
\begin{gathered}
C_{N}=\sum_{k=0}^{N}\left(F\left(z_{k+1}\right)-F\left(z_{k}\right)\right) \cdot Z_{0}\left(x_{k+1}\right)+\sum_{k=0}^{N} Z_{p}\left(x_{k+1}\right)+ \\
+\int_{0}^{T} \sum_{k=0}^{N} Z_{c}\left(x_{k+1}\right)\left[F\left(z_{k+1}\right)-F\left(z_{k}\right)\right] d t+\int_{0}^{T} \sum_{k=0}^{N} \int_{x_{k}}^{z_{k}} \varphi(x) Z_{\partial}\left(\frac{z}{x_{k}}\right) d x d t \rightarrow \min
\end{gathered}
$$

Then the problem of determining such a set $x_{k}, z_{k}$ for which the value will be minimal, arises.

The solution can be found by the random search method according to the structural diagram (Fig. 1).

In this way:

we define $N$;

we get $N-1$ random numbers from a set of uniformly distributed from 0 to $x_{N}$. Adding

$x_{N}$ to them and arranging them in ascending order, we get the previous row $z_{k}$;

getting $N$ random numbers from the same population, and the previous ones, we have the previous row $x_{\kappa}$;

replacing the values $x_{\kappa}$ and $z_{k}$ from the previous series in such a way that $z_{k} \geq x_{k}$, we get the series $z_{k}$ and $x_{k}$ for this attempt and perform the calculations $C_{N}$;

we repeat the cycle many times, memorizing the best option for $C_{N}$;

compare the results with $z_{k}=x_{k}$. 


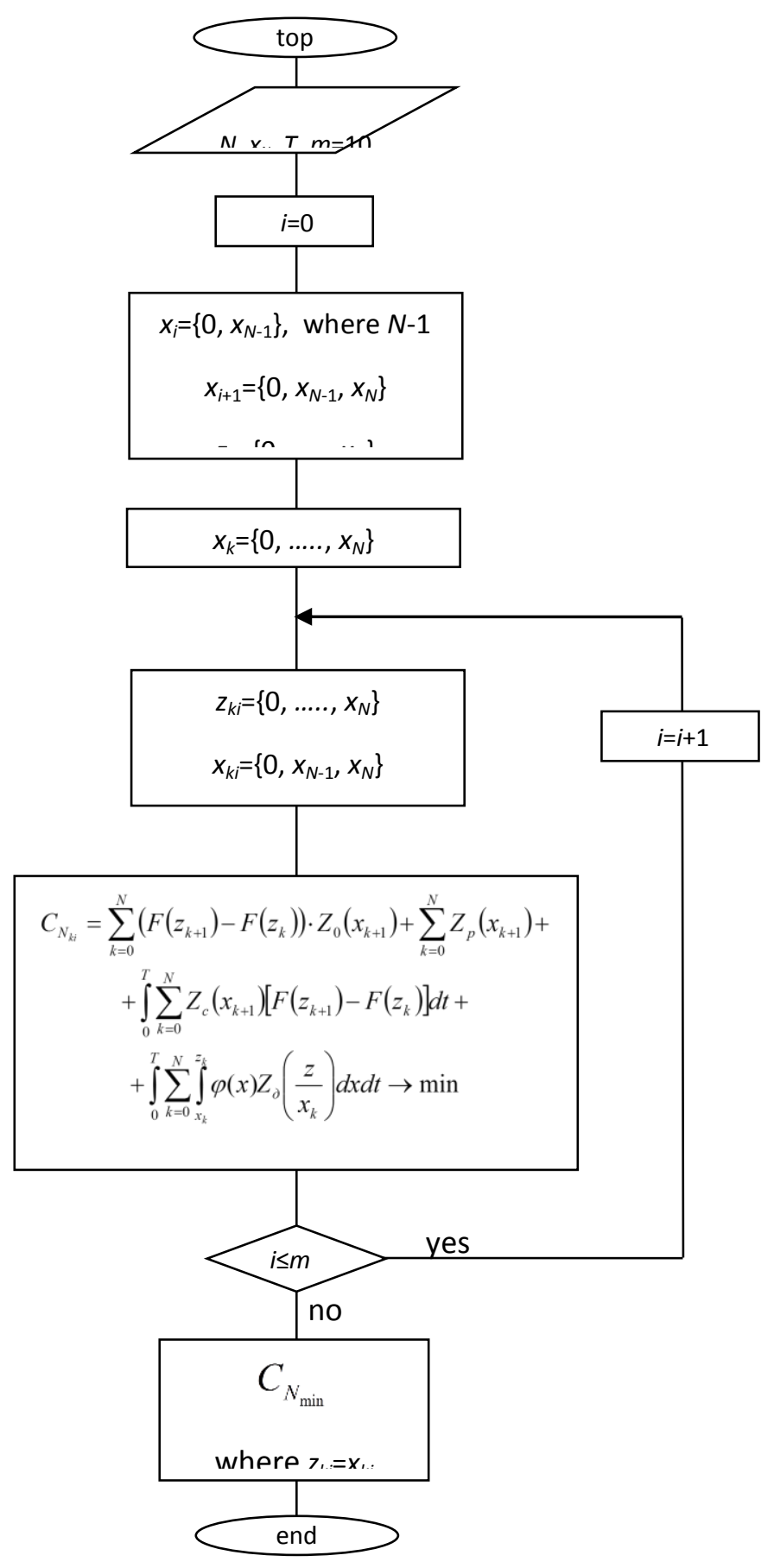

Fig. 1. Block diagram of the choice $x_{\kappa}, C_{N}$

Practice shows that dependence $Z_{\partial}\left(\frac{z}{x_{k}}\right)$ can be of a different nature.

In the first case, it is a step function 


$$
\begin{gathered}
Z_{\partial}\left(\frac{z}{x_{k}}\right)=0 \text { where } \frac{z}{x_{k}} \leq 1 ; \\
Z_{\partial}\left(\frac{z}{x_{k}}\right)=Z *_{\partial} \text { where } 1 \leq \frac{z}{x_{k}} \leq 2 ; \\
Z_{\partial}\left(\frac{z}{x_{k}}\right)=n Z *_{\partial} \text { where } n \leq \frac{z}{x_{k}} \leq n+1 .
\end{gathered}
$$

In the second case, it is a function of the following form

$$
\begin{aligned}
Z_{\partial}\left(\frac{z}{x_{k}}\right) & =0 \text { where } \frac{z}{x_{k}} \leq 1 \\
Z_{\partial}\left(\frac{z}{x_{k}}\right) & =k_{\partial}\left(\frac{z}{x_{k}}-1\right) \text { where } \frac{z}{x_{k}} \geq 1 .
\end{aligned}
$$

The second case is limiting with respect to the first case where $n \rightarrow \infty$.

In the first case, a heuristic method of solving the problem can be used. In the second case, we write the equation as follows

$$
\begin{gathered}
C_{N}=\sum_{k=0}^{N}\left[F\left(z_{k+1}\right)-F\left(z_{k}\right)\right] \cdot\left[Z_{0}\left(x_{k+1}\right)+\int_{0}^{T} Z_{c}\left(x_{k+1}\right) d t\right]+\sum_{k=0}^{N} Z_{p}\left(x_{k+1}\right)+ \\
+\sum_{k=0}^{N} \int_{x_{k}}^{v x_{k}} f(x)\left(\frac{x}{x_{k}}-1\right) d x \int_{0}^{T} k_{\partial} d t \rightarrow \min ,
\end{gathered}
$$

where $v=\frac{z_{k}}{x_{k}}$.

Due to the fact that $v$ is not a discrete quantity, it is very difficult to solve the problem. One of the possible methods of solution is a consistent search for $v$ while solving the problem of choosing the optimal series for each $v$.

Consider one of the cases of solving this problem. We accept the following assumptions

$$
\begin{gathered}
F(x)=b x \text { where } 0 \leq x \leq x_{N} \\
F(x)=0 \text { where } x \leq 0 \\
F(x)=b x_{N} \text { where } x \geq x_{N} .
\end{gathered}
$$

Let us estimate the change of expenses by the following dependences 


$$
\begin{aligned}
& Z_{0}(x)=a x \\
& Z_{p}(x)=c x \\
& Z_{c}(x)=e x .
\end{aligned}
$$

Then

$$
\begin{gathered}
f(x)=b \text { where } 0 \leq x \leq x_{N} \\
f(x)=0 \text { where } x<0 \text { where } x \geq x_{N} .
\end{gathered}
$$

Let us simplify the problem so that it is necessary to choose such value $x_{\kappa}$, assuming that one type of vehicles is used. In this case, $z_{k}=x_{N}$ and the expression (5) has the following form

$$
\begin{aligned}
& C_{N}=b x_{N}\left(a x_{k}+\int_{0}^{T} e x_{k} d t\right)+c x_{k}+\int_{x_{k}}^{x_{N}} b\left(\frac{x}{x_{k}}-1\right) d x \int_{0}^{T} k_{\partial} d t= \\
& =x_{k}\left[b x_{N}(a+e T)+c-\frac{1}{2} b k_{\partial} T\right]+\frac{b k_{\partial} T x_{N}^{2}}{2 x_{k}}-b k_{\partial} T x_{N} \rightarrow \min .
\end{aligned}
$$

Differentiating the expression (9) using $x_{\kappa}$, equating the derivative to zero and solving the equation, we find a formula for calculating the optimal value $x_{\kappa}$.

$$
\begin{aligned}
& y^{\prime}\left(x_{k}\right)=b x_{N}(a+e T)+c+\frac{1}{2} b k_{\partial} T+\frac{b k_{\partial} T x_{N}^{2}}{2 x_{k}}=0 \\
& x_{k}=x_{N} \sqrt{\frac{k_{\partial} T}{2 x_{N}(a+e T)+2 \frac{c}{b}+k_{\partial} T}} .
\end{aligned}
$$

If we get $x_{k}>x_{N}$, then we need to accept $x_{k}=x_{N}$.

To calculate the value $x_{k_{i}}$ for different service life of vehicles, the following initial data is accepted:

costs of production of one vehicle $Z_{0}\left(x_{k}\right)=10 \cdot 10^{6}$ hryvnia;

the cost of development, testing and installation for the production of vehicles $Z_{p}\left(x_{k}\right)=10^{6}$ hryvnia;

cost of operation of vehicles per unit time hryvnia;

additional costs per vehicle per unit time $Z_{\partial}\left(\frac{z}{x_{k}}\right)=0,3 Z_{c}\left(x_{k}\right)=0,3 \cdot 20 \cdot 10 \cdot 10^{6}$ hryvnia. 
The corresponding coefficients of equations (6), (7) are calculated for the standard service life $T=20$ years. Thus recalculation of years of operation in kilometers of run was carried out as follows.

$$
T_{\kappa м}=S_{\partial} \cdot t_{\partial / \mu} \cdot k_{M} \cdot T
$$

where $S_{\partial}$ - average daily mileage of vehicles, $S_{\partial}=300 \mathrm{~km} /$ per day;

$t_{\partial / \mu}$ - number of days per month, $t_{\partial / \mu}=30,4$ per day;

$k_{\mu}$ - number of months in a year, $k_{м}=12$ months;

$T$ - regulatory service life of vehicles.

Thus $T_{\kappa u}=S_{\partial} \cdot t_{\partial / \mu} \cdot k_{M} \cdot T=2,16 \cdot 10^{6} \mathrm{~km}$.

The following service life of vehicles $T_{1}=10$ years $\left(1 \cdot 10^{6} \mathrm{KM}\right), T_{2}=15$ years $\left(1,62 \cdot 10^{6} \mathrm{Kм}\right)$, $T_{3}=20$ years $\left(2,16 \cdot 10^{6} \mathrm{KM}\right)$ were accepted for calculation.

The coefficients of equations (6), (7) were determined for the service life of $T_{3}=20$ years.

$$
\begin{gathered}
a=\frac{Z_{0}\left(x_{k}\right)}{T_{3}} ; \quad a=\frac{10 \cdot 10^{6}}{2,16 \cdot 10^{6}}=4,63 \mathrm{hryvnia} / \mathrm{km} ; \\
c=\frac{Z_{p}\left(x_{k}\right)}{T_{3}} ; \quad c=\frac{10^{6}}{2,16 \cdot 10^{6}}=0,463 \mathrm{hryvnia} / \mathrm{km} ; \\
e=\frac{Z_{c}\left(x_{k}\right)}{x_{N} \cdot T_{3}} ; \quad e=\frac{20 \cdot 10 \cdot 10^{6}}{10^{3} \cdot 2,16 \cdot 10^{6}}=0,093 \mathrm{hryvnia} / \mathrm{km} ; \\
k_{\partial}=\frac{Z_{\partial}\left(\frac{x_{N}}{x_{k}}\right)}{T_{3}} ; \quad k_{\partial}=\frac{0,3 \cdot 20 \cdot 10 \cdot 10^{6}}{2,16 \cdot 10^{6}}=27,8 \mathrm{hryvnia} / \mathrm{km},
\end{gathered}
$$

where $x_{N}$ - maximum range of cargo delivery, $x_{N}=10^{3} \mathrm{~km}$.

The value of the coefficient $b$ is calculated for the entire period of operation of vehicles.

$$
b=\frac{1}{T_{3}} ; \quad b=\frac{1}{2,16 \cdot 10^{6}} \mathrm{~km}^{-1} .
$$

Values $x_{k_{i}}, C_{N_{i}}$ for the service life $T_{i}$ are calculated using Excel and are shown in Table 1. 
Table 1. Values of quantities $x_{k_{i}}, C_{N_{i}}$ for service life $T_{i}$

\begin{tabular}{|c|c|c|c|c|c|}
\hline Service life $T_{i}$, year & 10 & 15 & 20 & 25 & 30 \\
\hline Average daily mileage $x_{k_{i}}$, li & 260 & 320 & 360 & 400 & 430 \\
\hline Total costs $C_{N_{i}}$, hryvnia & 38816 & 43218 & 53116 & 55681 & 61913 \\
\hline
\end{tabular}

Graphic representations in the form $C_{N}=f(T), T=f\left(x_{\kappa}\right)$ are shown in Fig. 2

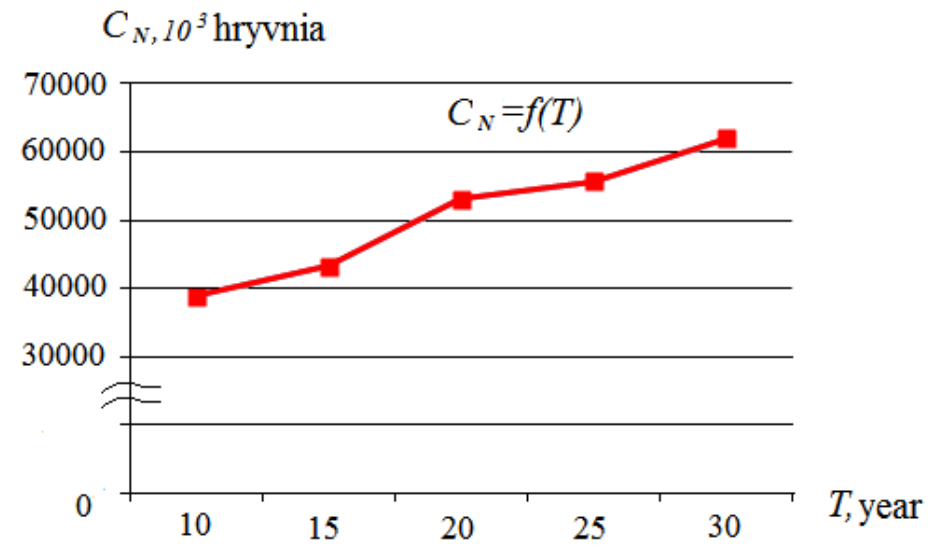

a)

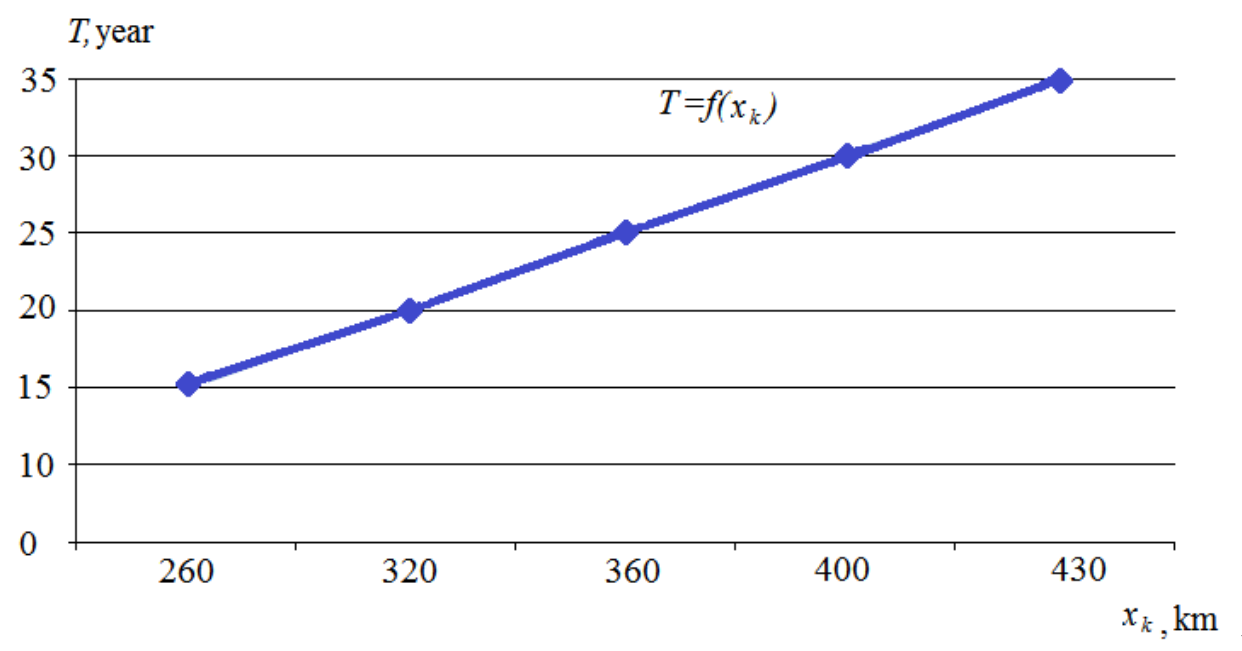

Fig. 2. Dynamics of dependencies a) $C_{N}=f(T)$, b) $T=f\left(x_{\kappa}\right)$

As it can be seen from the above dependencies (Fig. 2), to ensure a given average daily range of traffic at the appropriate service life $T$, it is necessary to comply with the mileage $x_{\kappa}$, taking into account the amount of costs $C_{N}$.

The nature of the change in costs from the service life at the optimal value according to 20 years increases, then slows down slightly to 25 years, but after this period increases again. 


\section{Conclusions}

1. When assessing the optimal service life of vehicles, the following costs must be taken into account such as the development of the vehicle, its creation, testing and production, the cost of operation and storage, as well as additional costs.

2. By modeling with the help of the developed algorithm, the optimal values $x_{k}$ and $C_{N}$ for a given vehicle with a period of use are determined. As it can be seen from the obtained dependencies, where large $T$, the meaning in carrying out additional measures for the maintenance of the vehicle disappears due to a significant decrease in the increase in value $x_{k}$.

3. The above provisions make it possible to make optimal decisions regarding the expediency of interaction among various modes of transport to ensure the implementation of the required transportation distance.

\section{REFERENCES}

1. Kotenko, A.M., Krasheninin, O.S., Shapatina, O.O. (2014). Udoskonalennia protsesu kombinovanykh perevezen vantazhiv [Improving the process of combined cargo transportation]. Skhidno-Yevropeiskyi zhurnal peredovykh tekhnolohii - Eastern European Journal of Enterprise Technologies, 4/3(70), 4-8 [in Ukrainian].

2. Panchenko, S., Lavrukhin, O., Shapatina, O. (2017). Creating a qualimetric criterion for the generalized level of vehicle. Eastern-European journal of enterprise technologies, 1/3(85), 39-45. DOI: 10.15587/1729-4061.2017.92203.

3. Lavrukhin, O., Zapara, V., Zapara, Y., Shapatina, O., Bogomazova, G. (2017). Investigation into the bimodal transportation process by modelling rail module states. Transport Problems, 12(2), 99-112. DOI: 10.20858/tp.2017.12.2.10.

4. Butko, T.V., Kostiennikov, O.M., Prokhorov, V.M., Shapatina, O.O. (2019). Rozrobka avtomatyzovanoi tekhnolohii planuvannia intermodalnykh perevezen na osnovi vektornoi optymizatsii [Development of automated technology for planning of intermodal transportations on the basis of multiobjective optimization]. Zbirnyk naukovykh prats Ukrainskoho derzhavnoho universytetu zaliznychnoho transportu - Collected scientific works of Ukrainian State University of Railway Transport, 188, 71-85 [in Ukrainian].

5. Dărăban, Ń.S., Stefănescu, P., Crisan, P. (2012). Economic Benefits of Developing Intermodal Transport in the European Union. Annals of the University of Oradea: Economic Science, 1(2), 81-87.

6. Tadić, S., Zečević, S. (2012). Development of Intermodal Transport and Logistics in Serbia. International Journal for Traffic and Transport Engineering, 2(4), 380-390.

7. Mindur, L., Hajdul, M. (2011). The Concept of Intermodal Network Development in Poland Using Multi-Agent Systems. Transport Problems: International Scientific Journal, 6(3), 5-16.

8. Islam, D.M.Z. (2014). Barriers to and enablers for European rail freight transport for integrated door-to-door logistics service. Part 1: Barriers to multimodal rail freight transport. Transport Problems: International Scientific Journal, 9(3), 43-56.

9. Islam, D.M.Z. (2014). Barriers to and enablers for European rail freight transport for integrated door-to-door logistics service. Part 2: Enablers for multimodal rail freight transport. Transport Problems: International Scientific Journal, 9(4), 6-13.

10. Nobbe, A., Molinari, M., Mistrangelo, D., Keese, T. (2012). Metrocargo: ein innovatives Konzept für intermodalen Gütertransport von Tür zu Tür [Metrocargo: an innovative concept for the intermodal door-to-door transport of freight]. Eisenbahntechnische Rundschau - Train Technology Review, 3, 26-28 [In German].

11. Havenga, Jan, H., Simpson, Z., Fourie, P. F., A. de. Bod. (2011). Sustainable Freight Transport In South Africa: Domestic Intermodal Solutions. Journal of Transport and Supply Chain Management, 5(1), 149-169.

12. Congli, Hao, Yixiang, Yue. (2016). Optimization on Combination of Transport Routes and Modes on Dynamic Programming for a Container Multimodal Transport System. Procedia Engineering, 137, 382-390.

13. Kaderavek, P. (2012). RailRunner Looks to Europe. Railvolution, 4/12, 126.

14. Krasheninin, O., Klymenko, O., Ponomarenko, O., Yakovlev, S. (2018). Justification of Statutory Service Life Extension of Locomotives on the Basis of Theory of Aging. International Journal of Engineering \& Technology, 7 (4.3), 174-178.

15. Tartakovskyi E.D., Ustenko O.V, Krasheninin O.S., Oboznyi O.M. (2012). Otsinka pokaznykiv TO pry podovzheni terminu ekspluatatsii TRS po narobtsi [Performance assessment of MS during the extended operation life of the TRS]. Zbirnyk naukovykh prats Ukrainskoi derzhavnoi akademii zaliznychnoho transportu - Collected scientific works of Ukrainian State University of Railway Transport, 132, 5-11 [in Ukrainian]. 


\section{Олександр Крашенінін ${ }^{1}$, Ольга Шапатіна ${ }^{2 *}$, Вімалій Пономаренко}

${ }^{1}$ Професор, Кафедра експлуатація та ремонт рухомого складу, Український державний університет залізничного транспорту, майдан Фейєрбаха, 7, м. Харків, 61050, Україна

${ }^{2}$ Старший викладач, Кафедра управління вантажною $\mathrm{i}$ комерційною роботою, Український державний університет залізничного транспорту, майдан Фейєрбаха, 7, м. Харків, 61050, Україна

${ }_{3}$ Старший викладач, Кафедра іноземні мови, Український державний університет залізничного транспорту, майдан Фейєрбаха, 7, м. Харків, 61050, Україна

\section{ОЦІНКА ТЕРМІНУ ЕКСПЛУАТАЦІЇ ТРАНСПОРТНИХ ЗАСОБІВ З УРАХУВАННЯМ ВПЛИВУ РЯДУ ЧИННИКІВ}

Сучасні транспортні засоби (ТЗ), щуо експлуатуються на залізницях України, майже вичерпали свій ресурс або його перевищили. Продовжується перевитрата фінансових і матеріальних ресурсів на їх утримання. Нормативний термін експлуатації ТЗ був розрахований на стабільні економічні умови використання ТЗ і своєчасне їх оновлення у міру старіння.

Термін експлуатаиії сучасних транспортних засобів визначається виливом багатьох чинників, не врахування яких може привести до значних витрат навіть при дотриманні нормативного терміну експлуатації.

Для залізничного транспорту иі чинники потребують сучасного уточнення, оскільки в експлуатаиії термін їх роботи часто перевищує нормативний або, як для інтермодального транспорту, взагалі термін експлуатаиії не має строгого обтрунтування.

Відповідно до цього в статті проаналізовані питання щодо оиінки впливу на термін експлуатачії ТЗ складових витрат на його утримання і середньодобового пробігу.

Показано, що, по-перше, визначення терміну експлуатації ТЗ необхідно ув'язувати з витратами на розробку ТЗ, його створення, випробування $i$ постановку на виробництво, витратами на експлуатацію і зберігання, а також з додатковими витратами, а, по-друге, з оптимальним показником середньодобового пробігу, при якому всі наведені витрати мінімальні.

Ключові слова: транспортний засіб, оптимальний середньодобовий пробіг, термін експлуатації, мінімальні приведені витрати. 